\title{
Engineering Economics based on International Economics
}

\author{
Giri Nurpribadi ${ }^{1}$, Erina Rulianti ${ }^{2}$ \\ Pelita Bangsa University \\ giri.nurpribadi@pelitabangsa.ac.id ${ }^{1}$,erina.rulianti@pelitabangsa.ac.id ${ }^{2}$
}

\begin{abstract}
The purpose of research is to determine International Business variables, involve BI interest rates, exchange rates and inflation to export performance. Methods use explanatory research level need data from Statistics institutions to provide determinations for independent variables for indicators, monthly and year to year (yoy). We use independent variables Inflation to explains pricing policies, and also foreign exchange for money market with exchange rates, good enough fluctuative.macroeconomics indicator. The Methods used in a quantitative methods at explanatory research.Statistics equation $\mathrm{F}$ $=2.462>\mathrm{F}$ Table $(3,32,5 \%)=1.152$. Hyphotheses received, $2.462>1.152$.with significantly $0.080=0 . t$ counted 2.030 with significantly $0.051=0$. $t$ Table interpolation 1.768. Inflation $=11.528 \%$,every $1 \%$ added,influencing increase export 11.528 ton..Inflation positive siginificantly, $2.030>1.768$.
\end{abstract}

Keywords: BI Rates, Export, Exchange Rates, Inflation, International Economics

\section{Introduction}

Location, as an object to determine tittle of research.Cikarang as the best locations Industrial Estate in South East Asia to involve Delta Silicon, EJIP, Hyundai,and also Jababeka.Overall the industrial estate to organize some employee to work about multiple job desciptions,divide at some work in organization systems. Preliminery Explaining about engineering economics adjustment at management substantial focus on combine between financial management and human resources management. Time Value of money component to involve interest rate as an indicator of engineering economics, and exchange rate as an indicator of International Economics.Engineering Economics not only sentences,but describing about Combination between Engineering and Economics,sometimes use in Project Cashflow Management.

Problem Solving about fundamental problem to purpose explaining influence interest rate to increase employee welfare, because loans systems in banking,for example influenced by monthly salary and power of corporate influenced by exchange rates. Accumulation of saving in every company cause effect by exchange rates,by foreign exchange trading in business environments area.

Fundamentally, exchange rates will be presented if the strengthening or weakening of the rupiah exchange rate was relevance dependent on fundamental and technical factors. Fundamental factors driving the strengthening of the rupiah include low inflation, a safe current account deficit,and a reduction in the difference of interest rate yields with the US Treasury. Meanwhile,technical factors affecting the movement of the rupiah are the level of risk premium The exchange rate the rupiah is still undervalued, after March 2020 had been displayed all research performance.

Generally, problems around the International Business systems to explains,more important if Indonesia Surplus, it means export trade greater than import trade, and also differentiate with deficit with explaining export less than import. Economic Policy usually placement exports 
activities more important,because entrepreneur attitudes and increasing good enough for Indonesia Economic Policy. Assumptions: Conventional Systems in Banking environments applying with interest rate to borrow some people who served by money credit transaction until returned it,and also tax applied by foreign exchange export resultsin trading floor.

Indonesia is developing country, and need policy to determine for Macroeconomic Strategic, Engineering economics based on International economics as a tittle with fundamental(exchange rates system), banking for loan saving and inflation variables to explains all problems in the future relationship between foreign exchange export results which responsibility banks to cut tax as same as possible about accumulation deposits interest rates with incremental systems. In the future,some people should be understood about financial problem.All decisions had been arranging in present,and on going to use financial circumstances such as macroeconomic variables, payment systems using forward rate. Recently,The development of microbiological strains problem solving focus on Corona viridae decreasing welfare, because capsid materials such as globula proteins have got capabilities to maximize limitation involving big scale social limitation, Information Technology had been practiced and applied. Information Systems, exchange rates on international trade with uncertainty decision making because welfare variables maybe not stabilize.Stabilization money policy occasionally need uncertainty,certainty and risk decision making analysis for international economics area.

\section{Literature Review}

\subsection{First Phase: Preliminery Research}

Literature with tittle An Analysis of Influencing interest rate The Central Bank of Indonesia and Export volume toward Exchange Rates. Research goals about the problem solving research is achieving the target of effect interest rate and quantity international trade to year rupiah exchange rate for five years.Author taken hypothesis to increase interest rate ,export import,rupiahs with exchange rate measurement by \$US had been lag. Research indication has significant effect to change rupiah exchange rate.Analyze the data by writer by using doubled linear analysis regresi with the typical models and also use the $\mathrm{F}$ test and $\mathrm{t}$ test. From the regression equation analysis.

Research methods was implemented by data analysis for farms export value of Zamrud Khatulistiwa to the Sam Uncle company, stock exchange data and Indonesia Central Bank.Secondary data with timeseries decomposition classification data.Methods of data analysis used in this study is the Statistics Concepts with a multinomial regression equation typical and tools arithmetic program SPSS,based on the regression counted using SPSS obtained R2 value of $76.12 \%$ indicates that the variation in the value of farms exports Indonesia Archipelago to USA, purpose is able to be explained simultaneously by variable one code exchange rates variable and second interest rate variable by $76.12 \%$ remaining $24.12 \%$. Regression coefficients value of variable rate $\left(\mathrm{X}_{1}\right)$ positive and significance impact on Indonesia's farms exports to the United States. Regression coefficients which have got variable exchange rate which is equal to 668 ,meaning that if there is an increase of 1.00 US\$ exchange rates, the value of Indonesia's farms exports to the United States have increasing US\$ 668 ,coefficient value from two phase variables is approximately -482 that the Indonesian of Central Bank rates negative effect and significance impact on the value of Indonesia's farms exports to the United States,meaning that a $1 \%$ increase in interest rates,will under the surface ofd atawer the level of Indonesia 's farms exports the US amounted to US\$ 482. 
Inflation, at this moment,should be understood about many definition on inflation as there are researcher with most concluding that inflation decreasing the purchasing value of currency.Next, some researcher define inflation as the rate at which the general level of prices for goods and services is rising and,consequently, the purchasing power of currency is wave hectic decreasing, provide a similar definition as they view it as a situation where prices consistently. increase with money decreasing until empty value.The definition to describe the situation in Kingdom Swatini.Thus, they defined inflation as an increase in domestic prices of the commodities more globally.Generally,understanding of inflation terms,however,based on the financial conceptual which money.

Interest rate.Some people defined interest rate as a value that is gained in the effort of a value that has been stored.and also with the other expert said interest rate is the price a borrowed pays for the use of borrowed money from a lender/borrower financial equity institutions or free paid on borrowers assets.Describing opinion regarding interest rate as the relationship between inflation and interest rate on the general behaviour of a given supply demand. Understood about research problem and also following the Fisher hypothesis suggest that there is a positive relationship between inflation and the interest rate in any highly economics social class in the privacy system. This wrote is based on the understanding that both variables are finance driven affecting both the demand and supply side of an economy as in the case of debtors and creditors for financial with debt collectors system with strength temperament. With opinion,to provide statement.

\subsection{Second Phase : International Textbooks}

Sophitischatedly,apart from welfare economic conditions, the recent developments in the liberalization of trade can be held partly responsible for growing trade figures.However,the decision of firms to internationalise has also made an important contribution.This internationalization and liberalization of trade have had a profound impact on international business.(Jepma and Rhoen,1996).[5]Interest rates, if financing is expressed in the vendor's currency, the interest rate to be applied is in principle the market rate. According the consensus, government at least,however,also grant an interest supplement or subsidy if the market rate is above the Consensus rate (Jepma and Rhoen,1996) [5].

An exchange rate is,simply, the price of one nation's currency in terms of another country.For example,the Singapore dollar exchange rate is just the number of SGD that one dollar will buy.Equivalently, the dollar/SGD exchange rate is the number off dollars one yen will buy. To understand how exchange rates are set it helps to recognize that they are market- clearing prices that equilibrium supplies and demands in stock exchange markets. The determinants of currency supplies and demands are first discussed with the aid of a two- country model featuring the United States and SGD.Later,the various currency influences will be learnerd more closely.

Equilibrium considering with $\mathrm{e} 1>\mathrm{e} 0$ results.In otherwords, a higher rate of inflation in the United States than in Singapore will arrange to a depreciation of the dollar relative to the SGD or,equivalently, to an appreciation of the mark relative to the dollar.In general,a nation running a relatively high rate of inflation will find its currency declining in value relative to the currencies of countries with lower inflation rates. This relationship provide statement as purchasing power parity. Depends on the currency value of the Singapore Dollar relative to the dollar,the amount of SGD appreciation or depreciation is computed as the fractional increase or decrease in the dollar value of the SGD\$..For example, if the SGD/\$ exchange rate goes from SGD $1=\$ 0.75$ to SGD $1=\$ 0.78$, the SGD said to have appreciated by $(0.78-0.75) / 0.75=$ $4.0 \%$. 


\subsection{Third Phase : Conceptual Frame of Research}

Explaining about relationship three independent variables and one independent variable should be place below at Figure 1 .

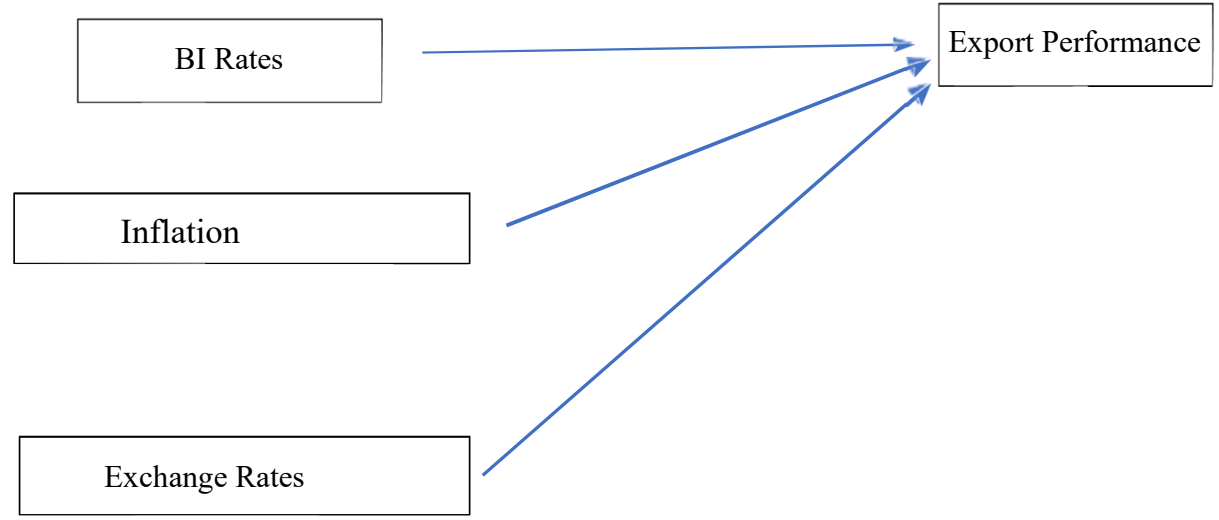

Fig. 1. Descriptions the Conceptual Frame of Research

\section{Methods}

Research Methods with quantitative equation need variable Central Bank Interest Rates, Exchange Rates Rupiahs and inflation with parameter standards United States of America, which explaining with every strength exchange rates, between IDR and US\$ will influence welfare employee.All the analysis at research tittle depends on quantitative methods. The purpose of research is to verify influencing macroeconomics variables to export variables.

As a holistic mindset, the logic systems which explaining about correlation between engineering economic concept and international economic concept, to analyze interest rates variable and exchange rate variable. Umbrella Question : Whats BI Rates, Exchange Rates, and Inflation simultaneously influencing dependent variables. Relevant with Umbrella questions, Research questions include variables with Hypothesis style :

H1.1 BI Rates provide influencing to Export Performance

H1.2 Exchange Rates provide influencing to Export Performance

H1.3 Inflation provide influencing to Export Performance.

Table 1. Data

\begin{tabular}{ccccc}
\hline Year & Export & Bank Indonesia Rates \% & Exchange Rates & Inflation \% \\
\hline 201701 & 123.08 & 4.75 & 13418 & 3.49 \\
201702 & 113.07 & 4.75 & 13295 & 3.83 \\
201703 & 126.63 & 4.75 & 13308 & 3.61 \\
\hline
\end{tabular}




\begin{tabular}{ccccc}
\hline Year & Export & Bank Indonesia Rates \% & Exchange Rates & Inflation \% \\
\hline 1704 & 159.49 & 4.75 & 13257 & 4.17 \\
201705 & 117.71 & 4.75 & 13231 & 4.33 \\
201706 & 131.15 & 4.75 & 13221 & 4.37 \\
201707 & 113.98 & 4.75 & 13258 & 3.88 \\
201708 & 114.74 & 4.50 & 13263 & 3.82 \\
201709 & 114.51 & 4.25 & 13269 & 3.72 \\
201710 & 131.19 & 4.25 & 13514 & 3.58 \\
201711 & 113.82 & 4.25 & 13432 & 3.30 \\
201712 & 107.51 & 4.25 & 13447 & 3.61 \\
201813 & 120.60 & 4.25 & 13431 & 3.25 \\
201814 & 116.43 & 4.25 & 13361 & 3.18 \\
201815 & 123.79 & 4.25 & 13677 & 3.40 \\
201816 & 115.33 & 4.25 & 13696 & 3.41 \\
201817 & 151.65 & 4.75 & 13895 & 3.23 \\
201818 & 111.10 & 5.25 & 13818 & 3.12 \\
201819 & 112.03 & 5.25 & 14346 & 3.18 \\
201820 & 122.68 & 5.50 & 14430 & 3.20 \\
201821 & 114.96 & 5.75 & 14766 & 2.88 \\
201822 & 126.8 & 5.75 & 15013 & 3.16 \\
201823 & 121.04 & 6.00 & 15014 & 3.23 \\
201824 & 134.87 & 6.00 & 14222 & 3.13 \\
201925 & 107.63 & 6.00 & 14402 & 2.82 \\
201926 & 108.01 & 6.00 & 13906 & 2.57 \\
201927 & 103.81 & 6.00 & 14078 & 2.48 \\
201928 & 104.48 & 6.00 & 14166 & 2.83 \\
201929 & 106.72 & 6.00 & 14211 & 3.32 \\
201930 & 109.29 & 6.00 & 14187 & 3.28 \\
201931 & 111.10 & 5.75 & 14089 & 3.32 \\
201932 & 112.15 & 5.50 & 14132 & 3.49 \\
201933 & 115.90 & 5.25 & 14146 & 3.39 \\
201934 & 115.24 & 5.00 & 14136 & 3.13 \\
201935 & 129.45 & 5.00 & 13932 & \\
201936 & 114.54 & 5.00 & & \\
\hline & & & & \\
\end{tabular}

Table 2. F Test

\begin{tabular}{cccccc}
\hline Model & Sum of Squares & Df & $\begin{array}{c}\text { Mean } \\
\text { Square }\end{array}$ & F & Sig. \\
\hline 1 & & & & & \\
Regression & 9469593,299 & 3 & 3156531,100 & 2,462 &, $080 \mathrm{~b}$ \\
Residual & 41034557,67 & 32 & 1282329,927 & & \\
Total & 50504150,97 & 35 & & & \\
\hline
\end{tabular}

Table 3. $t$ Test 


\begin{tabular}{cccccc}
\hline Model & $\begin{array}{c}\text { Unstandardized } \\
\text { Beta }\end{array}$ & $\begin{array}{c}\text { Coefficients } \\
\text { Std error }\end{array}$ & $\begin{array}{c}\text { Standardized Beta } \\
\text { Coefficients }\end{array}$ & t & Sig \\
\hline 1 (Constant) & $-283,951$ & $8,767,133$ & &,- 032 &, 974 \\
BI Rates & $-5,820$ & 4,618 &,- 320 & $-1,260$ &, 217 \\
Exchange Rates &, 008 &, 006 &, 347 & 1,252 &, 220 \\
Inflation & 11,528 & 5,878 &, 421 & 2,030 &, 051 \\
\hline
\end{tabular}

\section{Result and Discussion}

Export more important rather than import,although import needed if accumulation, availability of product/services very limited and use export as a main decision to conditioning dependent variables. From F test, $\mathrm{F}$ counted $=2.462$ with significantly level $0.080=0$ Because probability (0) less than 0.05 ,regression models capable to use export predictions.F test, $\mathrm{F}$ counted 2.462 greater than $\mathrm{F}$ table $(3,32,5 \%)=1.152$. Hypothesis received because 2.462 greater than 1.152 .

$\mathrm{t}$ test, $\mathrm{t}$ counted 2.030 with significantly $=0.051=0$, Inflation with intervening variable Consumer Price Index $t$ table ,interpolation 1.768. It means Regression Coefficents with indicator Inflation $=11.528 \%$, every $1 \%$ added, influencing increase export 11.528 ton. Inflation variable positive influencing significantly because 2.030 greater than 1.768 .

\section{Conclusion}

Results for Research Achievements with Regression Equation providing indications International Economics activities from International Business Theory focused on export performance as a dependent variable indicates ,inflation variable influencing significantly to increase export.Gains from trade will be more international profitabilities around terms of trade.All variables from hypotheses,only Inflation dominant to determine significantly.

\section{References}

[1] Adolf,H. dan Suryawinata R.P.,(2018) Law Principles in International Trade. RefikaAditama. Bandung.

[2] Beamish,P.W. and Delios,A. (2004)International Business an Asia Pacific Perspective Prentice 
Hall,Pearson Education South Asia Pte Ltd.Singapore.

[3] Boediono. (2018)International Economics.First Edition.BPFE.Yogyakarta.

[4] Gerber,J.(2018)International Economics.Seventh Edition.Global Edition Pearson Education Limited.London.

[5] Jepma,C. and Rhoen,A.(1996)International Trade : a business perspective. Addison Wesley Longman Limited.London

[6] Krugman,P.R.,Melitz,M.J., and Obstfeld,M. (2012)International Economics.Theory and Policy.Ninth Edition, Addison Wesley,New York.

[7] Nopirin.(2014)International Economics.Third Edition. BPFE. Yogyakarta.

[8] Pugel,T.A.(2016)International Economics.Sixteenth Edition.McGraw Hill Edition.New York.

[9] Salvatore,D.(2013)International Economics.John Wiley and Sons.NewYork.

[10] Shapiro, A.C.(1999)Multinational Financial Management,Sixth Edition. John Wiley and Sons.New York.

[11] Hadi,S. Yudha,A.E.An Analysis Influencing Interest Rate Central Bank and Volume Eksport Import to Exchange Rates.Vol 7 (1).(2009)

[12] Khumalo,L.C, Kodua,A.A.,and Mutambara,E. Relationship between inflation and interest rates in Swaziland Revisited.Banks and Bank Systems.Vol 12.(2017) 